\title{
Salt and blood pressure in Belgium
}

\author{
J. STAESSEN, R. FAGARD, P. LIJNEN, AND A. AMERY \\ From the Hypertension and Cardiovascular Rehabilitation Unit, Department of Pathophysiology, University of \\ Leuven, Belgium
}

\section{BULPITT}

From the Department of Medical Statistics and Epidemiology, London School of Hygiene and Tropical Medicine

\section{J. V. JOOSSENS}

From the Division of Epidemiology, School of Public Health, Leuven, Belgium

SUMMARY Blood pressure, pulse rate, body weight, and height were measured on two occasions in the inhabitants of a random $10 \%$ sample of households in a Belgian village. Twenty-four-hour urinary excretion of creatinine, sodium, and potassium was also determined. In subjects over the age of 19 there was a significant correlation for both systolic and diastolic pressure with age and body weight and, in women, also with pulse rate. After adjusting for these three variables, the systolic blood pressure in men was negatively correlated with the daily urinary potassium excretion, and the diastolic blood pressure in women negatively with the urinary sodium: creatinine ratio.

The present data, obtained within one society, do not support a role for dietary sodium in the distribution of blood pressure within this population. Comparison of the present results with data from other countries does not refute the salt-genetic hypothesis but suggests also that a high potassium intake may lower blood pressure.

According to the salt-genetic hypothesis an excessive salt intake in genetically susceptible individuals may lead to an increase in blood pressure and eventually to the development of hypertension. A positive relationship between salt intake and blood pressure has been demonstrated in rats. ${ }^{1}$ In humans the salt-genetic hypothesis has also received much attention and has been discussed by Freis, ${ }^{2}$ Simpson, ${ }^{3}$ Swales, ${ }^{4}$ Joossens, ${ }^{5}$ and Amery et al. ${ }^{6}$

Isolated societies have been described ${ }^{7 \rightarrow}$ where the sodium intake is low, and where blood pressure does not increase with advancing age. It is not clear whether these observations can be extrapolated to Western societies. Food habits may be different in relation not only to salt intake but also, for example, to potassium intake and calorie consumption. Also, genetic differences have to be considered. It is therefore more relevant to study the relationship between salt intake and blood pressure within Western industrialised societies. The purpose of the present study was to investigate this relationship in a sample of a Belgian community, and to compare the results with those obtained in Scotland, as reported recently by Beevers $e t$ al. ${ }^{10}$

\section{Material and methods}

A village of 12400 inhabitants was studied, a random sample of $10 \%$ of the households identified, and all members born before 1970 were invited to participate in the present study. This report is confined to the subjects born before 1960. After excluding teenagers, and subjects who had recently moved from the village, 694 people were eligible for the study.

Each household was visited twice by trained volunteers. The first home visit consisted of five consecutive blood pressure readings in the sitting position, followed by a pulse rate count and a measurement of body weight and height. A self-administered questionnaire and a bottle for a 24-hour urine collection were given to each participant. At the second visit, two to five weeks later, the questionnaire and a recent 24-hour urine 
sample were collected and the measurements of blood pressure, pulse rate, body weight, and height were repeated. Disappearance of the Korotkoff sounds (phase 5) was used as an indicator of the diastolic blood pressure. The means of the 10 blood pressure measurements and of the two determinations of pulse rate, body weight, and height were used to characterise each subject.

Results of blood pressure, pulse rate, and body weight determinations were available in 480 subjects, and 24-hour urine samples in 468. The response rate was therefore $69 \%$ and $67 \%$ respectively. Of the 480 participants, 45 were taking drugs known to reduce blood pressure; their mean age was $59 \pm 2 \cdot 1$ years, and their blood pressure $144 \pm 3 \cdot 0 / 81 \pm 1.6 \mathrm{~mm} \mathrm{Hg}$. Fourteen were men and 31 women. Their mean daily urinary sodium excretion was $144 \pm 8.9 \mathrm{mmol}$, and their potassium excretion $61 \pm 4.9 \mathrm{mmol}$. These subjects were excluded from further analysis. Urinary creatinine excretion was plotted against body weight for each sex separately, and after excluding subjects who fell outside the two standard deviations range, 410 urine collections were left for the present analysis.

Blood pressure was correlated with the urine and other measurements for both sexes separately, using Pearson's correlation coefficients and significance levels derived from 2-tailed tests. In order to determine the independent effects of the anthropometric and urine measurements, multiple regression equations were calculated using the stepwise (step-up) procedure, terminating when a non-significant regression coefficient was entered.

\section{Results}

The general characteristics of the subjects are given in Table 1. Fig. 1 shows the systolic and diastolic blood pressure according to age in men and women, and Fig. 2 the daily urinary sodium and potassium excretion. Using first-order correlations, systolic and

Table 1 Results obtained for the male and female subjects (mean values $\pm S E M)$

\begin{tabular}{lcc}
\hline & Men & Women \\
\hline No. & 233 & 202 \\
Age (years) & $41.0 \pm 0.94$ & $40.4 \pm 1.05$ \\
Systolic blood pressure (mm Hg) & $133.1 \pm 0.88$ & $128.2 \pm 1.12$ \\
Diastolic blood pressure (mm Hg) & $78.3 \pm 0.63$ & $75.6 \pm 0.74$ \\
Pulse rate (beats/minute) & $74.7 \pm 0.57$ & $75.1 \pm 0.60$ \\
Body weight (kg) & $75.6 \pm 0.73$ & $65.2 \pm 0.97$ \\
Height (cm) & $173.8 \pm 0.45$ & $161.3 \pm 0.42$ \\
Urinary volume (1/day)* & $1.40 \pm 0.037$ & $1.25 \pm 0.039$ \\
Creatinine excretion (mmol/day) & $15.9 \pm 0.29$ & $11.6 \pm 0.24$ \\
Sodium excretion (mmol/day) & $182.2 \pm 4.62$ & $148.4 \pm 3.90$ \\
Potassium excretion (mmol/day) & $70.0 \pm 1.57$ & $60.5 \pm 1.30$ \\
Urinary sodium: creatinine ratio & $11.7 \pm 0.29$ & $12.8 \pm 0.28$ \\
Urinary sodium: potassium ratio & $2.9 \pm 0.08$ & $2.5 \pm 0.06$ \\
\hline
\end{tabular}

*24-hour urine samples were analysed for 215 male and 195 female subjects.

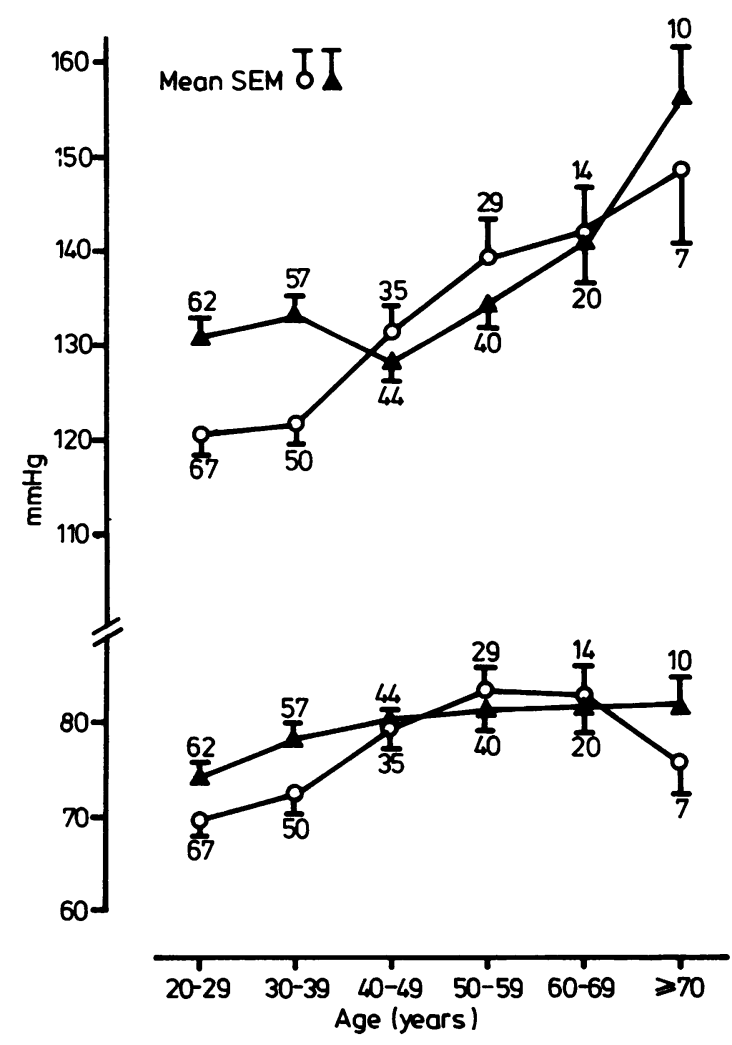

Fig. 1 Systolic and diastolic blood pressure (mean Istandard error) according to age in males ( $)$ and females (O). The number of subjects in each age group is given for both sexes.

diastolic blood pressure were significantly and positively related to age and body weight in both sexes and, in women, also to pulse rate (Table 2). Systolic and diastolic blood pressure were not related to the urinary excretion of sodium or potassium, nor to the urinary sodium : creatinine and sodium : potassium ratio in either sex (Table 2). The use of a logarithmic transformation for the urinary variables did not materially alter these correlation coefficients.

Since several of the variables under consideration were closely interrelated, a multiple regression equation was calculated for systolic and diastolic blood pressure in both sexes separately (Table 3 ). The blood pressure was mainly related to age and body weight. Systolic blood pressure was significantly and positively related to pulse rate in women. In men systolic blood pressure was significantly and negatively related to urinary potassium excretion (Table 3). The first-order correlation between systolic blood pressure and potassium excretion was not significant and equal to $-0 \cdot 11$ (Table 2). 


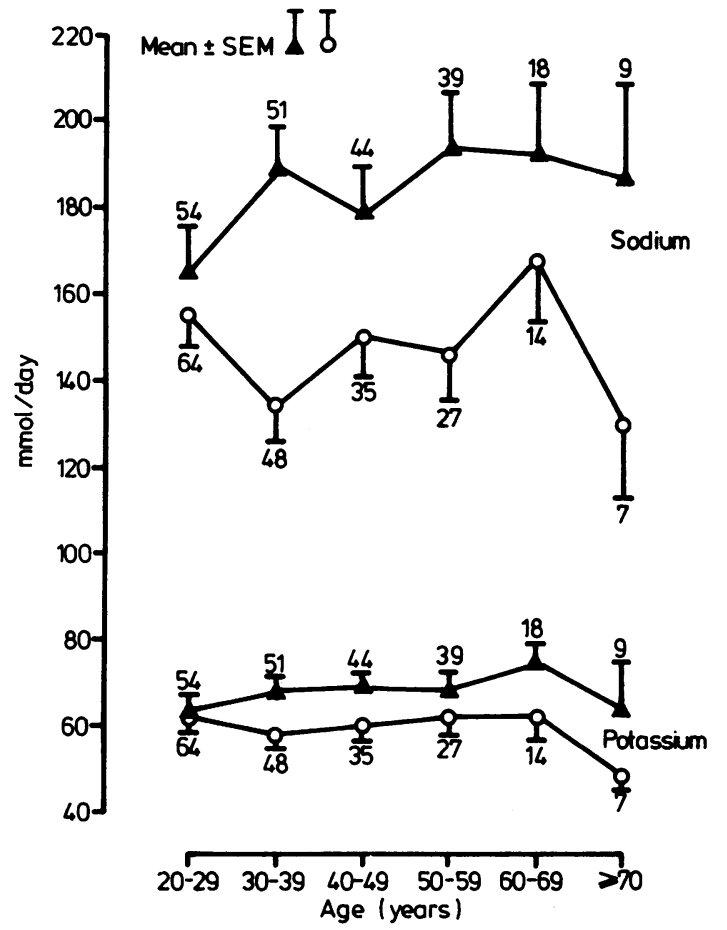

Fig. 2 Daily urinary sodium and potassium excretion, expressed in millimoles (mean \pm standard error), according to age in males ( $\Delta$ and females (O). The number of subjects in each age group is given for both sexes.

However, after adjusting for age and weight, the correlation was significant at the $0.1 \%$ level. As 24-hour urine collections are sometimes incorrect (incomplete or collected for more than 24 hours) urinary excretion of sodium was related to potassium and creatinine excretion using the sodium : potassium and sodium: creatinine ratio. The daily sodium excretion and the sodium : potassium ratio were not related to blood pressure in the male and female sample. However, in women diastolic blood pressure was negatively and significantly related to the sodium : creatinine ratio, after adjusting for age and body weight (Table 3).

\section{Discussion}

BLOOD PRESSURE

This report confirms the age-related changes in systolic and diastolic blood pressure reported previously in Belgium by Kesteloot et $a l^{11}$ and Demanet $e a^{12}$ and also in Scotland by Hawthorne et al. ${ }^{13}$

Taking a diastolic blood pressure of $90 \mathrm{~mm} \mathrm{Hg}$ or more, Hawthorne $e a^{13}$ found at primary screening of subjects, aged 45 to 64 , a $39.8 \%$ prevalence of hypertension in a Scottish community. Using the same criteria in our Belgian sample, we observed a $30.8 \%$ prevalence of hypertension, which was lower $(p<0.05)$ than in the Scottish population. It is not known to what extent this was due to the use of different measurement techniques or to the conditions under which blood pressure was measured. In the present study the blood pressures were measured in the homes of the subjects, where the atmosphere was possibly more relaxed, while the Scottish investigators measured the blood pressure in special examination centres.

Blood pressure readings were available in $69 \%$ of the Belgian sample and in $79 \%$ of the Scottish. There is no indication that increasing the response rate in the present study would alter the results substantially. Indeed, $46 \%$ of the present sample was reached after a first contact, and after a second effort an additional $23 \%$ was successfully approached. No significant differences in blood pressure were observed between those seen initially and those contacted later.

The higher prevalence of hypertension in Scotland than in Belgium is consistent with the one-third excess of stroke mortality in Scotland compared with Belgium in the 1970s. ${ }^{14}$

Table 2 First-order correlation coefficients between blood pressure and other variables

\begin{tabular}{|c|c|c|c|c|}
\hline & \multicolumn{2}{|l|}{ MEN } & \multicolumn{2}{|l|}{ WOMEN } \\
\hline & $S B P$ & $D B P$ & $S B P$ & $D B P$ \\
\hline $\begin{array}{l}\text { Age } \\
\text { Body weight } \\
\text { Pulse rate } \\
\text { Creatinine excretion } \\
\text { Sodium excretion } \\
\text { Potassium excretion } \\
\text { Urinary sodium : creatinine ratio } \\
\text { Urinary sodium : potassium ratio }\end{array}$ & $\begin{array}{l}+0.32 * * \\
+0.27^{* *} \\
+0.17^{* *} \\
-0.09 \\
-0.05 \\
-0.11 \\
+0.04 \\
+0.05\end{array}$ & $\begin{array}{r}+0.30^{* * * *} \\
+0.34^{* * *} \\
+0.09 \\
-0.02 \\
+0.06 \\
0.00 \\
+0.07 \\
+0.05\end{array}$ & $\begin{array}{l}+0.51^{* * *} \\
+0.42^{* * *} \\
+0.23^{* *} \\
+0.15^{*} \\
+0.07 \\
+0.07 \\
-0.05 \\
-0.01\end{array}$ & $\begin{array}{l}+0.64^{* * *} \\
+0.46^{* * *} \\
+0.14^{*} \\
+0.06 \\
-0.02 \\
+0.02 \\
-0.10 \\
-0.07\end{array}$ \\
\hline
\end{tabular}

Significance of first-order correlation coefficients: "p $<0.05 * * p<0.01 * *{ }^{* *} p<0.001$ 
Table 3 Partial regression coefficients between blood pressure and different variables in multiple regression analysis

\begin{tabular}{|c|c|c|c|c|}
\hline & \multicolumn{2}{|l|}{$M E N$} & \multicolumn{2}{|l|}{ WOMEN } \\
\hline & $S B P$ & $D B P$ & $S B P$ & $D B P$ \\
\hline $\begin{array}{l}\text { Age } \\
\text { Body weight } \\
\text { Pulse rate } \\
\text { Urinary creatinine } \\
\text { Urinary sodium } \\
\text { Urinary potassium } \\
\text { Urinary } \mathrm{Na}: \text { creatinine ratio } \\
\text { Urinary } \mathrm{Na}: \mathrm{k} \text { ratio }\end{array}$ & $\begin{array}{l}+0 \cdot 28 * * * \\
+0 \cdot 34^{* * *} \\
\text { NS } \\
\text { NS } \\
\text { NS } \\
-0 \cdot 13^{* * *} \\
\text { NS } \\
\text { NS }\end{array}$ & $\begin{array}{l}+0 \cdot 16 * * * \\
+0 \cdot 25^{* * *} \\
\text { NS } \\
\text { NS } \\
\text { NS } \\
\text { NS } \\
\text { NS } \\
\text { NS }\end{array}$ & $\begin{array}{l}+0.51^{* * *} \\
+0 \cdot 28^{* * *} \\
+0 \cdot 36^{* * *} \\
+0 \cdot 27^{*} \\
\text { NS } \\
\text { NS } \\
\text { NS } \\
\text { NS }\end{array}$ & $\begin{array}{l}+0 \cdot 27^{* * *} \\
+0 \cdot 27^{* * *} \\
\text { NS } \\
\text { NS } \\
\text { NS } \\
\text { NS } \\
-0 \cdot 32^{*} \\
\text { NS }\end{array}$ \\
\hline $\begin{array}{l}\text { Multiple correlation coefficient (R) } \\
\text { Constant }\end{array}$ & $\begin{array}{r}0 \cdot 44 \\
104 \cdot 4\end{array}$ & $\begin{array}{l}0.41 \\
53 \cdot 1\end{array}$ & $\begin{array}{l}0.64 \\
53 \cdot 7\end{array}$ & $\begin{array}{l}0.59 \\
50.8\end{array}$ \\
\hline
\end{tabular}

NS = not significant, and therefore not included in the multiple regression.

"p $<0.05 *$ * $p<0.01 \quad * * p<0.001$

Table 4 Comparison between Scotland (Beevers et al 198010) and Belgium (present study) for male and female normotensives aged $45-64$

\begin{tabular}{|c|c|c|c|c|}
\hline & \multicolumn{2}{|l|}{$M E N$} & \multicolumn{2}{|l|}{ WOMEN } \\
\hline & Scotland & Belgium & Scodland & Belgium \\
\hline $\begin{array}{l}\text { No. } \\
\text { Urinary volume (1/day) } \\
\text { Creatinine excretion (mmol/day) } \\
\text { Sodium excretion (mmol/day) } \\
\text { Potassium excretion (mmol/day) } \\
\text { Urinary sodium : potassium ratio } \\
\text { Urinary sodium : creatinine ratio } \\
\text { Urinary potassium : creatinine ratio }\end{array}$ & $\begin{array}{l}45 \\
1.69 \pm 0.082 \\
12 \cdot 1 \pm 0.51 \\
196 \pm 9.2 \\
47 \pm 3.0 \\
4.2 \dagger \\
16.2 \pm 0.80 \\
3.9 \dagger\end{array}$ & $\begin{aligned} 59 & \\
1 \cdot 50 & \pm 0.064 \\
15 \cdot 4 & \pm 0.51^{* \cdots *} \\
191 & \pm 9.3 \\
69 & \pm 2 \cdot 4^{* * *} \\
2 \cdot 8 & \pm 0.11^{* * *} \\
12 \cdot 6 & \pm 0.53^{* * *} \\
4 \cdot 6 & \pm 0.15^{* * *}\end{aligned}$ & $\begin{array}{l}47 \\
1.63 \pm 0.077 \\
9.7 \pm 0.36 \\
173 \pm 7.8 \\
46 \pm 2.7 \\
3.8 \dagger \\
17.8 \pm 0.72 \\
4.7 \dagger\end{array}$ & $\begin{aligned} 43 \\
1.44 \\
10.9 \pm 0.074 \\
147 \pm 0.42 \\
63 \pm 2 \cdot 5^{*} \\
2 \cdot 4 \pm 0 \cdot 10^{* * *} \\
13 \cdot 5 \pm 0.52^{* \cdots *} \\
5.9 \pm 0.21^{* \cdots *}\end{aligned}$ \\
\hline
\end{tabular}

***p<0.001 *p<0.01 *p<0.05: significance of the difference between Scotland and Belgium (for each sex separately).

+Variance assumed to be the same as in the Belgian sample for the calculation of the statistical difference between both countries.

URINARY SODIUM AND POTASSIUM EXCRETION The daily urinary sodium and potassium excretion was used in this report as an index for the sodium and potassium intake. ${ }^{15}$

The present results can be compared with the data from Scotland ${ }^{10}$ by restricting the sample to untreated normotensive subjects (diastolic blood pressure less than $90 \mathrm{~mm} \mathrm{Hg}$ ) aged 45 to 64. As shown in Table 4, the potassium excretion was significantly $(p<0.001)$ higher in Belgium than in Scotland for both sexes. Apart from a real difference in the potassium intake this could also be due to overcollection in Belgium or undercollection in Scotland. However, the urine volumes were on average lower in Belgian subjects of both sexes. Also the potassium : creatinine ratios were significantly higher in Belgium, the latter being less dependent on the completeness of the urine collections.

By contrast, sodium excretion was significantly lower in Belgian women and the sodium : creatinine ratio was significantly lower for both sexes in Belgium. Thus, the sodium : potassium ratios were also significantly lower in Belgium.

SALT AND BLOOD PRESSURE

The present study and mos't other investigations ${ }^{1016-19}$ within a single society have failed to detect a significant linear correlation between blood pressure and urinary sodium excretion.

Before accepting that these findings invalidate the salt hypothesis, other possibilities should be considered. It is possible that subjects with a high blood pressure intentionally decrease their sodium consumption. Furthermore, one single 24-hour urine collection could be an inadequate index of the sodium intake for an individual at that time $\mathrm{e}^{20-22}$ and does not give any indication of his previous sodium intake. Similarly, the blood pressure of a given individual may be more accurately characterised by readings taken over a longer period of time. In addition, Western populations have a high average sodium intake. If a positive association between sodium consumption and blood pressure exists only below some 'threshold', it is possible that this relationship is therefore not observed in these Western societies. Populations with a lower sodium intake may be preferable for testing the salt hypothesis. Finally, it is probable that factors other than genetics and sodium intake influence blood pressure; these factors could become so important that they override the influence of sodium which is then hard to detect in epidemiological studies in the population at large. 
In intervention trials, where sodium intake is changed and other factors are held as constant as possible, it is likely that the possible influence of sodium intake could be detected more easily. If the salt-genetic hypothesis is correct, the most suitable population for such an intervention trial would be patients with essential hypertension, since they have shown their susceptibility to sodium by developing high blood pressure under the existing conditions of sodium intake. Such intervention studies in hypertensive patients have been reported ${ }^{23-28}$ and reviewed recently. ${ }^{6}$ In these studies a reduction in urinary sodium output of 100 millimoles was associated with an average fall in systolic pressure of $11 \mathrm{~mm} \mathrm{Hg}$ and a fall in diastolic pressure of $10 \mathrm{~mm} \mathrm{Hg}{ }^{8}$ However, no results are available of controlled intervention trials in the community on the influence of sodium restriction on blood pressure, cardiovascular morbidity or mortality. Therefore, restriction of sodium intake in the population at large is based on indirect evidence, which was considered insufficient by Berglund et al. ${ }^{27}$

In fact Beevers et $a l^{10}$ and Berglund et $a l^{28}$ found a slightly lower urinary sodium excretion in hypertensive subjects than in normotensives. In the present study there was also a negative relationship between the sodium:creatinine ratio and the diastolic blood pressure in women, after correcting for age and body weight.

POTASSIUM AND BLOOD PRESSURE

In salt-treated rats, potassium administration reduced blood pressure ${ }^{29}$ and enhanced survival. ${ }^{30}$ Meneely and Battarbee ${ }^{31}$ have proposed that the high-sodium low-potassium diet of Western civilised societies, operating on a genetic substratum of susceptibility, may be the cardinal factor in the genesis of essential hypertension.

Some recent studies in man $^{18}{ }^{32}$ have demonstrated a negative relationship between blood pressure and the 24-hour urinary potassium excretion, although other investigators ${ }^{33}{ }^{34}$ have not observed such a relationship. The present study showed in Belgian men a negative and significant $(p<0.001)$ relationship between urinary potassium excretion and systolic blood pressure after correcting for age and body weight (Table 3 ). The partial regression coefficient indicates that for an increase in potassium excretion of $20 \mathrm{mmol}$ (the difference between Belgian and Scottish men), the systolic blood pressure would be reduced by $2 \cdot 2 \mathrm{~mm} \mathrm{Hg}$.

In Belgium, where the prevalence of hypertension appears to be lower than in Scotland, we found in normotensives not only a lower sodium : creatinine ratio but also a higher potassium excretion, leading to a higher potassium : creatinine and a lower sodium : potassium ratio (Table 4). The comparison between both countries, and the negative relationship between systolic blood pressure and potassium excretion in Belgian men, suggest that potassium intake may influence the blood pressure response to sodium (or vice versa), and that a high-potassium diet may protect against the development of hypertension in genetically susceptible individuals.

This study was made possible through the active and continued co-operation of the 'Gezondheidsraad' of the village under investigation. We thank the general practitioners for their support and the many volunteers for their devoted help in collecting the data. Mrs. R. Roussel-Deruyck and Mr. H. Hoogwijs performed the computer analysis. We gratefully acknowledge the technical and secretarial assistance of Mrs. K. Van Horenbeeck-Bijttebier, Mrs. M. Cober-Stinissen, and Mrs. Y. Vanhulst-Toremans. Part of the research of this laboratory is supported by grants from the Belgian research institutes NFWO and IWONL.

Reprints from Dr. J. Staessen, Inwendige Geneeskunde-Cardiologie, University Hospital Sint Rafael, Capucijnenvoer 35, B-3000 Leuven, Belgium.

\section{References}

${ }^{1}$ Dahl LK. Salt and hypertension. Am J Clin Nutr 1972; 25: 231-44.

${ }^{2}$ Freis ED. Salt, volume and the prevention of hypertension. Circulation 1976; 53: 589-95.

${ }^{3}$ Simpson FO. Salt and hypertension: a sceptical review of the evidence. Clin Sci 1979; 57: suppl: 463-80.

4 Swales JD. Dietary salt and hypertension. Lancet 1980; i: 1177-9.

${ }^{5}$ Joossens JV. Stroke, stomach cancer, and salt. A clue to the prevention of hypertension. In: Kesteloot $\mathbf{H}$, Joossens JV, ed. Epidemiology of arterial blood pressure. The Hague: Martinus Nijhoff Medical Division, 1980: 489-508.

- Amery A, Bulpitt C, Fagard R, Staessen J. Does diet matter in hypertension? Eur Heart $J$ 1980; 1: 299-308.

${ }^{7}$ Prior AM, Evans JG, Harvey HPB, Davidson F, Lindsay $M$. Sodium intake and blood pressure in two Polynesian populations. N Engl J Med 1968; 279: 515-20.

- Page LB, Damon A, Moellering RC. Antecedents of cardiovascular disease in six Solomon Island Societies. Circulation 1974; 49: 1132-46.

' Oliver WJ, Cohen EL, Neel JV. Blood pressure, sodium intake, and sodium related hormones in the Yanomamo Indians, a no-salt culture. Circulation 1975; 52: 146-51.

${ }^{10}$ Beevers DG, Hawthorne VM, Padfield PL. Salt and blood pressure in Scotland. Br Med J 1980; 281: 641-2. 
${ }^{11}$ Kesteloot H, Van Houte O. An epidemiologic survey of arterial blood pressure in a large male population group. Am J Epidemiol 1974; 99: 14-29.

${ }^{12}$ Demanet JC, Samii K, Rorive G, Maus Y, Coussaert E, Smets P. Blood pressure distribution and determinants in a sample of adolescent and adult Belgian population. Results of the Belgian Hypertension Committee Epidemiological Survey 1973-1977. In: Kesteloot H, Joossens JV, ed. Epidemiology of arterial blood pressure. The Hague: Martinus Nijhoff Medical Division. 1980: 121-44.

${ }^{18}$ Hawthorne VM, Greaves DA, Beevers DG. Blood pressure in a Scottish town. Br Med J 1974; iii: 600-3.

14 World Health Organisation. World health statistics annual 1. Geneva: WHO, 1977.

${ }^{15}$ Mikelsen O, Mokdani D, Gill JL, Frank RL. Sodium and potassium intakes and excretions of normal men consuming sodium chloride or a 1:1 mixture of sodium and potassium chloride. Am J Clin Nutr 1977; 30: 2033-40.

${ }^{16}$ Miall WE. Follow-up study of arterial pressure in the population of a Welsh mining valley. $\mathrm{Br} \mathrm{Med} J \mathrm{1959}$; iv: 1204-10.

${ }^{17}$ Dawber TR, Kannel WB, Kagan A, Donabedian RK, McNamara PM, Pearson G. Environmental factors in hypertension. In: Stamler J, Stamler R, Pullman TN, ed. The epidemiology of hypertension. Proceedings international symposium Chicago. New York: Grune \& Stratton, 1967: 255-88.

${ }^{18}$ Grim CE, Luft FC, Miller JZ, Meneely GR, Battarbee HD, Hames CG, Dahl LK. Racial differences in blood pressure in Evans County Georgia: relationship to sodium and potassium intake and plasma renin activity. J Chronic Dis 1980; 33: 87-94

${ }^{19}$ Simpson FO, Waal-Manning HJ, Bolli P, Phelan EL, Spears GFS. Relationship of blood pressure to sodium excretion in a population survey. Clin Sci Mol Med 1978 ; 55, suppl: 373-5.

${ }^{20}$ Langford HG, Watson RL. Electrolytes, environment and blood pressure. Clin Sci Mol Med 1973; 45, suppl: 111-3.

${ }^{21}$ Liu K, Cooper R, McKeever P, Byington R, Soltero I, Stamler R, Gosch F, Stevens E, Stamler J. Assessment of the association between habitual salt intake and high blood pressure: methodological problems. $A m$ J Epidemiol 1979; 110: 219-26.

${ }^{22}$ Joossens JV, Claessens J, Geboers J, Claes JH. Electrolytes and creatinine in multiple 24-hour urine collections (1970-1974). In: Kesteloot H, Joossens JV, ed. Epidemiology of arterial blood pressure. The Hague: Martinus Nijhoff Medical Division, 1980: 45-63.

${ }^{23}$ Parijs J, Joossens JV, Van der Linden L, Verstreken G, Amery A. Moderate sodium restriction and diuretics in the treatment of hypertension. Am Heart J 1973; 85: 22-34.

${ }^{2}$ Morgan T, Gillies A, Morgan G, Adam W, Wilson M, Carney $S$. Hypertension treated by salt restriction. Lancet 1978; i: 227-30.

${ }^{25}$ Kawasaki T, Delea CS, Bartter FC, Smith H. The effect of high-sodium and low-sodium intakes on blood pressure and other related variables in human subjects with idiopathic hypertension. Am J Med 1978; 64: 193-8.

${ }^{26}$ van Brummelen P, Schalekamp M, de Graeff J. Influence of sodium intake on hydrochlorothiazide-induced changes in blood pressure, serum electrolytes, renin and aldosterone in essential hypertension. Acta Med Scand 1978; 204: 151-7.

${ }^{27}$ Berglund G. Should salt intake be cut down to prevent primary hypertension? Acta Med Scand 1980; 207: $241-4$.

${ }^{28}$ Berglund $G$, Wikstrand $\mathrm{J}$, Wallentin I, Wilhemsen $\mathrm{L}$. Sodium excretion and sympathetic activity in relation to severity of hypertensive disease. Lancet 1976; i: 324-8.

${ }^{20}$ Dahl LK, Leiti G, Heine M. Influence of dietary potassium and sodium/potassium molar ratios on the development of salt hypertension.J Exp Med 1972; 136: 318-30.

${ }^{30}$ Meneely GR, Ball COT. Experimental epidemiology of chronic sodium chloride toxicity and the protective effect of potassium chloride. Am J Med 1958; 25: 713-25.

${ }^{31}$ Meneely GR, Battarbee HD. High sodium-low potassium environment and hypertension. Am J Cardiol 1976; 38: 768-85.

${ }^{32}$ Walker WG, Whelton PK, Saito H, Russell RP, Hermann J. Relation between blood pressure and renin, renin substrate, angiotensin II, aldosterone and urinary sodium and potassium in 574 ambulatory subjects. Hypertension 1979; 1: 287-91.

${ }^{33}$ Gros G, Weller JM, Hoobler SW. Relationship of sodium and potassium intake to blood pressure. Am J Clin Nutr 1971; 24: 605-8.

"Doyle AE, Chua KG, Duffy S. Urinary sodium, potassium and creatinine excretion in hypertensive and normotensive Australians. Med J Aust 1976; 2: 898-900. 